\title{
Soft-sediment deformation structures in seismically affected deep-sea Miocene turbidites (Cilento Basin, southern Italy)
}

\author{
Alessio Valente ${ }^{1, *}$, Andrzej Ślączka ${ }^{2}$, Giuseppe Cavuoto ${ }^{3}$ \\ ${ }^{1}$ Dipartimento di Scienze e Tecnologie, Università del Sannio, Via dei Mulini 59a, 82100 Benevento, Italy; \\ e-mail: valente@unisannio.it \\ ${ }^{2}$ Institute of Geological Sciences, Jagiellonian University, Oleandry 2, 30-063 Krakow, Poland; \\ e-mail: andrzej.slaczka@uj.edu.pl \\ ${ }^{3}$ Istituto per l'Ambiente Marino Costiero, CNR, Calata Porta di Massa, Porto di Napoli 83, 80133 Napoli, Italy; \\ e-mail: giuseppe.cavuoto@iamc.cnr.it \\ *corresponding author
}

\begin{abstract}
Soft-sediment deformation structures (SSDS) are widespread in the upper part of the S. Mauro Formation (Cilento Group, Middle-Late Miocene). The succession is represented mainly by thick and very thick, massive, coarse-grained sandstones, deposited by rapid sedimentation of high-density turbidity currents. The most common SSDS are short pillars, dishes, sedimentary sills and convolutions. They occur mostly in the upper parts of sandstone beds. Vertical tubes of $4-5 \mathrm{~cm}$ in diameter and up to $50 \mathrm{~cm}$ long constitute the most striking structures. They begin in the middle part of sandstone beds, which are basically massive or contain faint dish structures. These tubes can bifurcate upwards and/ or pass into bedding-parallel veins or dikes. The vertical tubes sometimes form sand volcanoes on the then sedimentary surface.

The SSDS are interpreted as the result of earthquake-triggered liquefaction and/or fluidisation of the turbidites that were affected by the seismic shocks. This implies that the deformed layers should be considered as seismites.
\end{abstract}

Keywords: High-density turbidites, soft-sediment deformation structures, seismites, Apennines, Cilento Group, Miocene, Italy

\section{Introduction}

In ancient turbidite deposits, syn-depositional sedimentary structures attributable to dewatering of unlithified sandy sediments occur frequently (Lowe, 1975, 1976; Stow \& Johansson, 2000). Their characteristics (type and size) are related to the grain size, texture and thickness of the deposits, as well as to the pore-fluid pressure, the rate of dewatering, the volume of expelled water, and the degree of compaction of the sediments. Their formation occurs either during (or immediately after) deposition or during consolidation (early diagene- sis) and is strictly connected to liquefaction and/or fluidisation processes.

Liquefaction is marked by the collapse of the grain framework in a bed and the rapid and temporary increase of the pore-fluid pressure. In this case, dish structures and small pillars in a re-established grain-supported texture originate. Liquefied sands may preserve undeformed or slightly deformed primary structures. Fluidisation, which is often associated with liquefaction, takes place when a fluid flowing vertically upwards through a granular aggregate exerts a sufficient drag force on the grains to lift or suspend them momentarily against the 
force of gravity. In response to this quick or liquefied state, fluidisation structures such as pillars and tabular, bed-parallel sedimentary bodies develop in a fluid-supported texture. Primary sedimentary structures usually are not preserved in fluidised sand beds.

The objective of the present contribution is to describe and discuss the genesis of fluidisation-related structures, which are exceptionally abundant in an over $100 \mathrm{~m}$ thick coastal section of the upper part of the Cilento Group (Miocene, southern Apennines).

\section{Geological setting}

The deposits under study crop out in the northern margin of the Cilento Group, previously known as the Cilento Flysch (Ietto et al., 1965; Pescatore, 1966; Cieszkowski et al., 1992, 1994), one of the major geological units outcropping extensively in the western part of the southern Apennines, close to the Tyrrhenian Sea (Fig. 1). They represent a typical example of a wedge-top basin and are Middle-Late Miocene in age (Amore et al., 1988; Cammarosano et al., 2004). They developed in front of the eastwards-advancing inner Apennine orogeny, upon an earlier deformed thrust-nappe (Liguride and Sicilide Units) derived from an oceanic and transitional accretionary complex ('Internides') subsequently overthrusting the outer Apennine platform.

The deposits of the Cilento Group are over $2 \mathrm{~km}$ thick and mainly consist of gravity-flow deposits, mostly siliciclastic but subordinately calcareous (Fig. 2), that originated in a marine basin. According to petrological data (Critelli, 1987; Critelli \& Le Pera, 1990; 1994) and palaeocurrent analysis (Pescatore, 1966), the clastic material was supplied from the basin margins and deposited in a tectonically active setting. In general terms, the Cilento Group deposits show an upward coarsening trend and can be subdivided lithostratigraphically into (1) the coarse-grained Pollica Formation (sensu Martelli et al., 2005) that is dominated by quartzitic sandstones and (2) a conglomerates-sandstones-mudstones succession of the S. Mauro Formation.

The stratigraphic interval investigated for its SSDS is located in the highest part of the S. Mauro Formation. The S. Mauro Formation crops out over large areas in the Cilento Basin (Fig. 1). It consists mainly of coarse- to medium-grained sandstone beds intercalated with fine-grained turbidites, marly-calcarenitic and arenaceous-pelitic couplets with tabular geometry, interpreted as the widest and flattest part (sheet shape) of a sand-rich depositional system (Cavuoto et al., 2004). External factors (tectonics, volcanism and climate) were active in the Miocene (Critelli, 1999; Meulenkamp \& Sissingh, 2003) and are reflected in the syn-sedimentary evolution of the basin margins which entailed extreme and anomalous changes in volume, frequency and composition of gravity flows in the basin.

Several volcanoclastic episodes represented by debris of rhyolithes/rhyodacites as well as by chaotic deposits of tuffites in the Pollica and S. Mauro
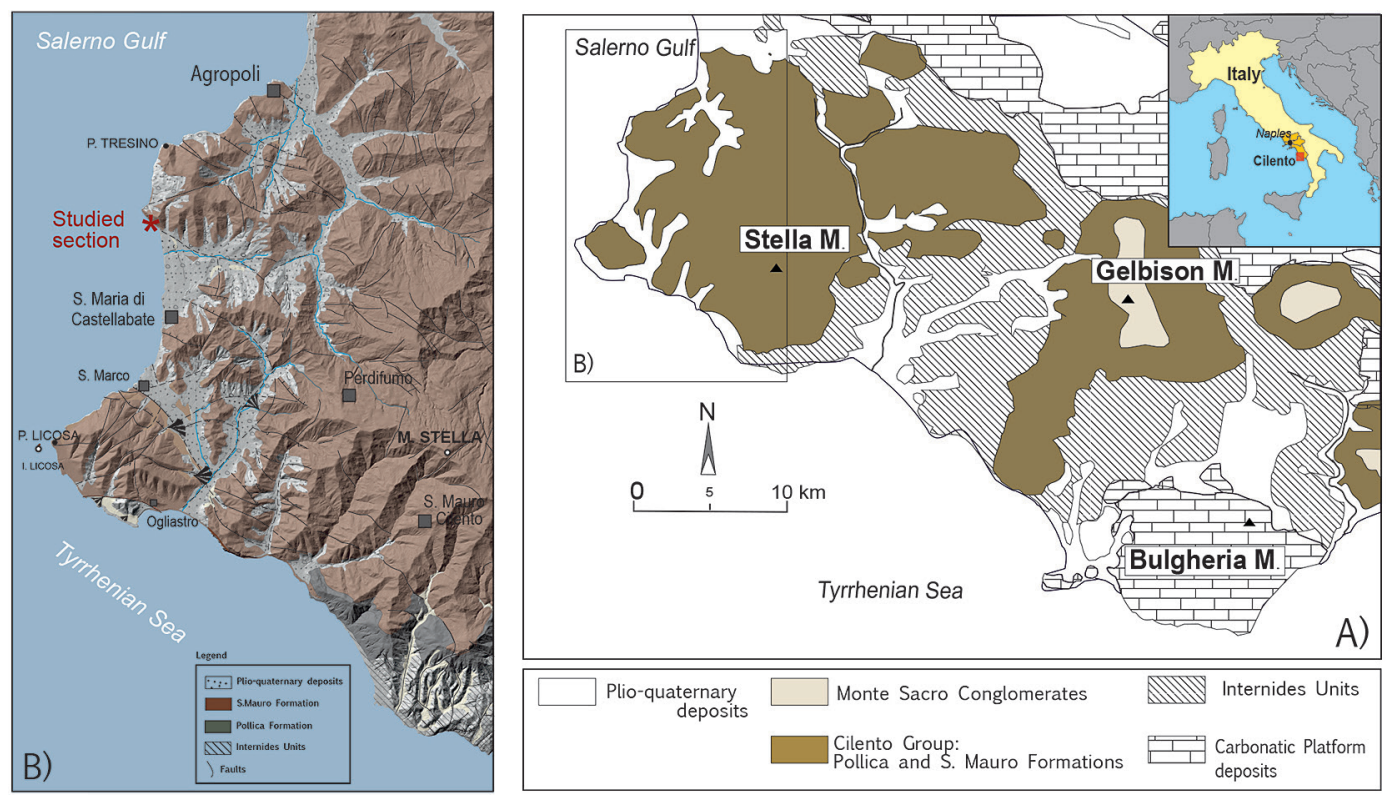

Fig. 1. Location maps.

A: Schematic geological map of the Cilento area (southern Apennines); B: Map of the study area and location of the section under study. 
Formations, point out a syn-depositional volcanic activity (Critelli \& Le Pera, 1994). The extensive presence in these formations of slumps, slides, debris flows and mudflows highlights the gravity-driven character, induced by seismically induced slope failure.

Other records of major allocyclic activity in the S. Mauro Formation are two 'megaturbidites', derived from a reworked calcareous megabed (Cieszkowski et al., 1995), each several tens of metres thick (Fig. 2 ) and related to olistostromes with extrabasinal

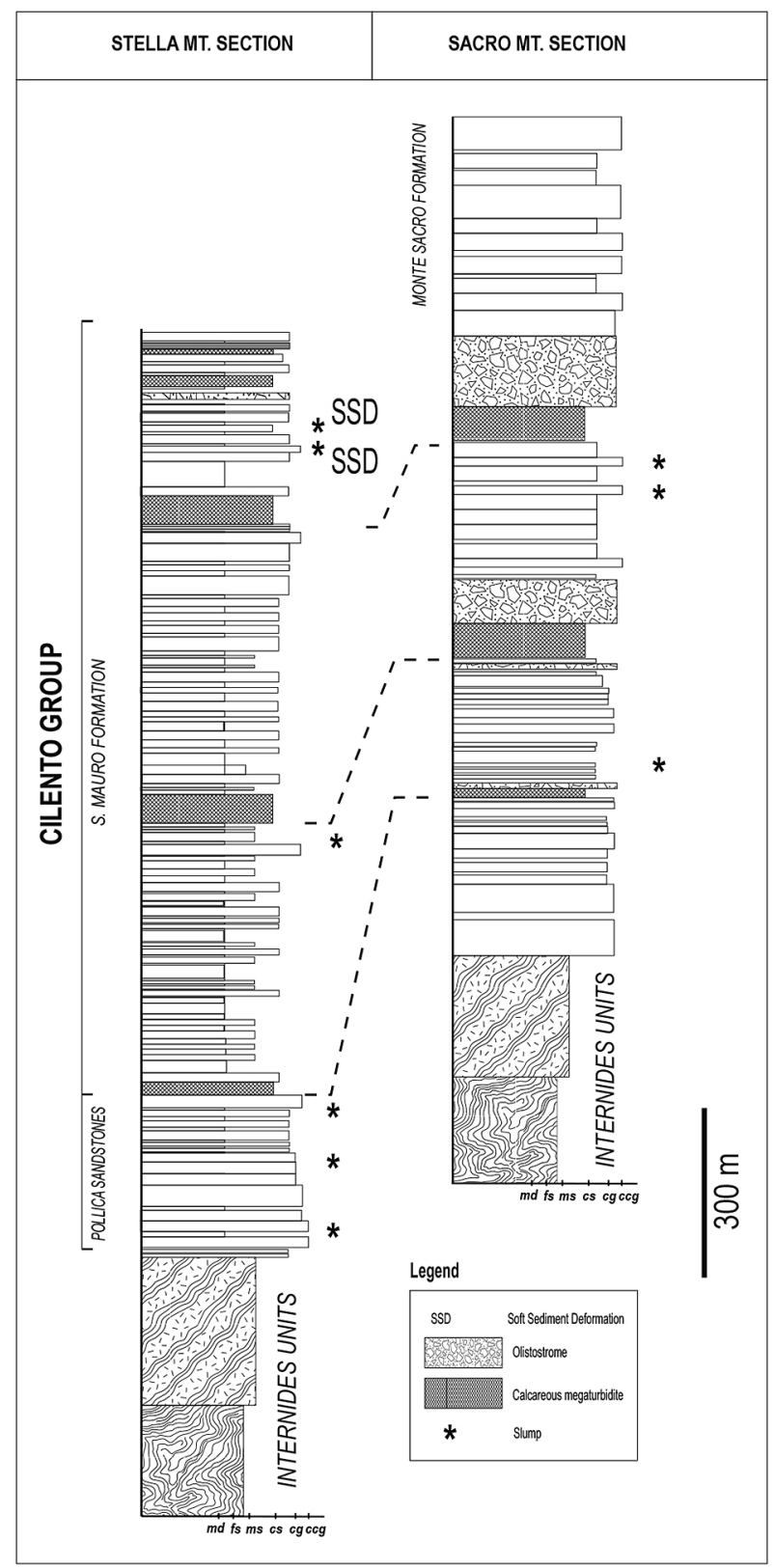

Fig. 2. Schematic lithological log of the Cilento Group in the sections of Stella Mt. and Gelbison (Sacro) Mt. Note the stratigraphic position of the soft-sediment deformation structures. material. These deposits were formed as a result of exceptional collapse and/or discharge of non-lithified material that was probably remobilised by a seismic shock related to a strong tectonic phase affecting the basin margins (Cavuoto et al., 2004).

\section{Description of the outcrops}

The investigated section (Fig. 3) is exposed for more than $200 \mathrm{~m}$ along the sea cliff of Monte Tresino, south of Agropoli. It represents the upper part of the succession outcropping in the Stella Mt. area, and corresponds to the topmost part of the S. Mauro Formation (Cilento Group, Fig. 2). The sediments which form this part of the S. Mauro Formation consist mainly of thick and very thick (up to $4 \mathrm{~m}$ ) sandstone beds that are often amalgamated. They are accompanied by subordinate medium to thin beds forming cycles, some of them fining upwards, some of them coarsening upward. Slump bodies occur in the upper part of the section.

The microfauna from samples collected from this outcrop in the 1960s suggest an age not older than Oligocene to earliest Miocene (Aquitanian) (Cocco, 1971). Recently obtained data, however, imply an early Tortonian age of the uppermost part of the S. Mauro Formation (Russo et al., 1995; Cammarosano et al., 2004).

The thick sandstone beds are mainly massive and generally coarse- to very coarse-grained. Upward grading is sometimes present, but only in the lowermost part of the beds where some grains over $2 \mathrm{~mm}$ (class A2 and B as defined by Pickering et al., 1989). In the lowermost part of some beds continuous, crude, thick $(0.5-2 \mathrm{~cm})$ and parallel laminae are present (Ślączka \& Thompson, 1981). Layers

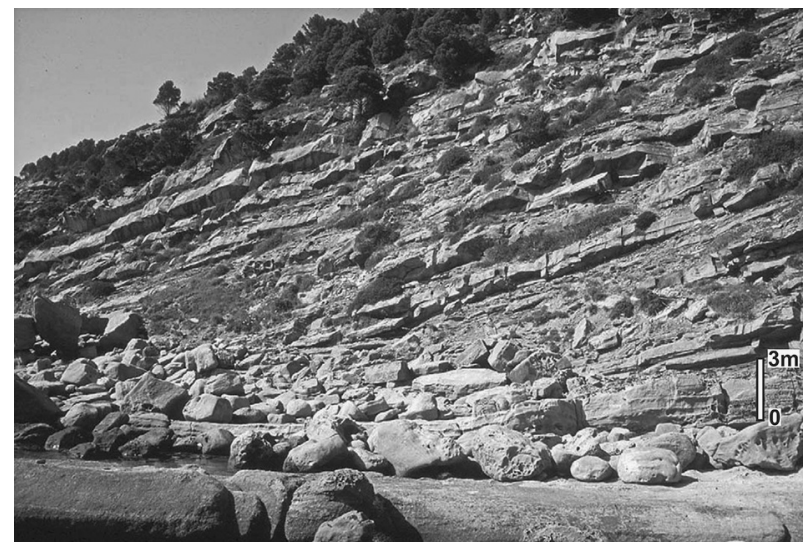

Fig. 3. The investigated section at Punta Tresino consisting of continuous, parallel, medium to very thick beds. The lowermost layer on the right site is $4 \mathrm{~m}$ thick (lower right). 
with soft-sediment deformation structures (SSDS) are abundant in this section. The SSDS show a wide variety of shapes and occur in units that are sandwiched between undeformed beds. The SSDS consist mainly of tubes, pillars and bedding-parallel sand intrusions (called 'sills' in the following).

Most of the thicker beds are tabular with sharp bases, which may display sole marks. Sporadically, peculiar elongated structures reminiscent of large sand waves can be seen in the lowermost part of the thickest beds that stretch perpendicular to the current direction. Mud clasts (Fig. 4) are present in considerable abundance. They vary in size, shape, abundance and position in the bed.

The thinner-bedded sandstones usually show normal grading, plane-parallel and ripple cross-laminae, and generally pass gradationally upwards into pelitic deposits (like the Bouma sequences $\mathrm{T}_{\mathrm{a} \text {-e }}$ or class $\mathrm{C}$ and D of Pickering et al., 1989). Massive beds or completely fluidised/convoluted beds exist as well. The thinner beds are generally laterally persistent at outcrop scale. Their bases are flat with scarce and small erosional features; some very coarse-grained beds show loadcasts up to 20 $\mathrm{cm}$ deep. Mottled intervals and small tubes in some sandstone beds may be of organic origin. In the higher part of the studied succession trace fossils are clearly visible at the bottom of some beds. Longitudinal ridges (cf. Allen, 1982), a few centimetres in height, almost parallel or slightly winding, are present in some internal horizontal surfaces within the uppermost parts of the beds. The ridges are coarser than the sediment hosting them. The trends of the ridges are commonly perpendicular to the current direction, which was - based on flute casts and cross-bedding measurements - on average $254^{\circ}$. Locally, the cross-bedding shows an opposite current direction. In a few cases ripples and associated back-flow ripples are present in the upper part of the same bed. The pelitic intervals are usually thin, ranging from no more than a few centimetres to some decimetres. In the upper part of the exposure, marly calcareous layers become thicker, reaching $220 \mathrm{~cm}$.

The deformed sandstones in this section are coarse- to very coarse grained, rarely medium-grained; only in the uppermost part of the beds finer sediments, consisting mainly of silt and clay, are present. Macroscopically the sandstones are moderately well sorted (Inclusive Graphic Standard Deviation < 0.8) with a silt matrix (generally $<5 \%$ ). The rocks are feldspar-rich arkoses, with commonly angular and subangular grains, closely packed with a small amount of cement and matrix. The main components are quartz, feldspars (micro- cline, albite, perthite), micas (muscovite and biotite) and chlorite, with subordinate amounts of igneous rocks (mainly granitoids), metamorphic rocks (gneisses, migmatites, quartzites, quartzitic schists) and a variety of limestones and sandstones.

This kind of succession was interpreted by Mutti et al. (1994) and Stow \& Johansson (2000) as a stacked lobe complex within a submarine fan (Valente, 1993; Cavuoto et al., 2004), consisting for a large part of turbidites.

\section{Soft-sediment deformation structures}

The SSDS are distributed over almost all layers of the studied section, confined in a discrete stratigraphical horizon of a hundred metres thick. These deformations have a good lateral continuity in each deformed bed, even though some of them show a low deformational intensity. The deformed layers contain abundant water-escape structures, pointing at liquefaction and sometimes at fluidisation. The sediment inside the liquefaction structures is generally coarser than that within the host rocks; it is moderately sorted (Inclusive Graphic Standard Deviation $>0.8$ ) and contains a small amount of mud. The sand grains are held together by a matrix of detrital mud and locally by calcite cement. Ferruginous cement is locally associated with the clay matrix. The calcite cement is medium to coarse crystalline, or poikilotopic (i.e., elements of various sizes with larger crystals enclosing smaller crystals of another mineral).

\subsection{Tubes}

The most spectacular and common SSDS are vertical and subvertical tubular bodies (Fig. 5A), $<5$ $\mathrm{cm}$ in diameter and over $20 \mathrm{~cm}$ long. In the exposed succession, the tubes are straight, sinuous or irregular in shape, whereas in plan view they are usually circular (cf. Mount, 1993) or elliptical. The tube usually begins in the massive part of a bed as a simple feature, but in the upper part it may bifurcate or join with other nearby tubes and sills. All these elements together locally resemble the sandstone dikes and sills described by Dżułyński \& Walton (1965), Beaudoin et al., (1983) and Parise \& Beaudoin (1986).

In the upper laminated parts of the beds these tubes cross laminae. Sporadically the tubes end as funnel-shaped structures (cf. Chen et al., 2009) or sand volcanoes. In other cases, these SSDS stop at the base of a laminated bed. As mentioned above, the sandy infill of the tubes is usually coarser and 


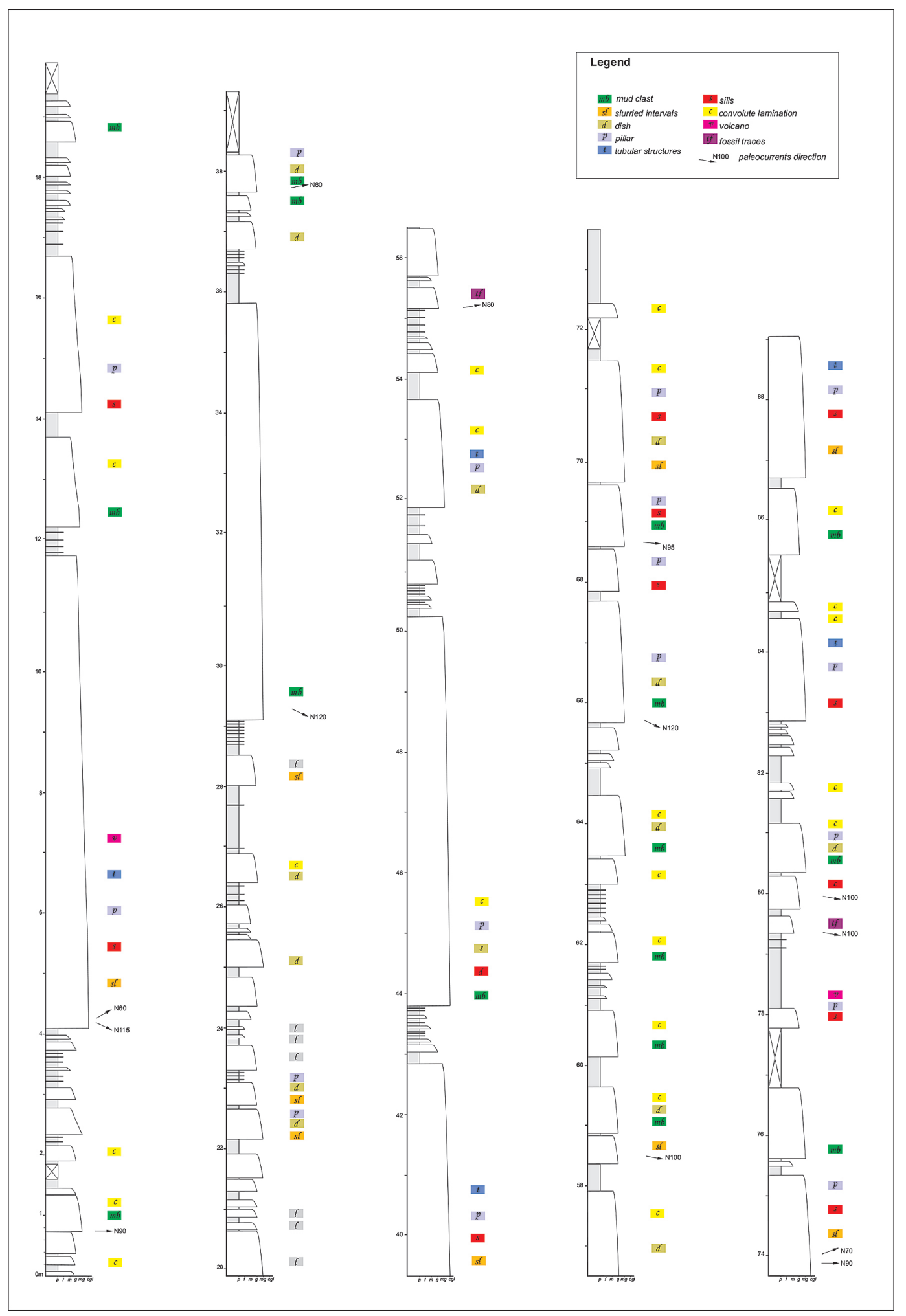

Fig. 4. Distribution of the sedimentary characteristics of the middle Cilento Group along the cliff of Monte Tresino. The total measured thickness of the succession is about $89 \mathrm{~m}$. Letters indicate the types of soft-sediment deformation structures, placed at their corresponding stratigraphic positions. Explanation of symbols: $\mathrm{mc}=$ mud clasts, $\mathrm{sl}=$ slurred intervals, $\mathrm{d}=$ dish structures, $\mathrm{p}=$ pillar structures, $\mathrm{t}=$ tubular structures, $\mathrm{s}=$ sedimentary sills, $\mathrm{c}=$ convolute laminations, $\mathrm{fl}=$ interval completely fluidised, $\mathrm{v}=$ sand volcano, $\mathrm{tf}=$ trace fossils, arrow $=$ palaeocurrent direction based on flute and groove casts; $\mathrm{p}=$ silt, $\mathrm{f}=$ fine sand, $\mathrm{m}=$ medium sand, $\mathrm{mg}=$ coarse sand, $\mathrm{g}=$ very coarse sand, $\mathrm{cgl}=$ gravel 
less well sorted than the grains constituting the host sandstone.

The tubes are also often associated with dish structures in the fine-grained and laminated, uppermost parts of the beds. Sometimes they are developed in the core of the anticlines of convolute lamination. Sporadically some tubes are exceptionally straight and have a more or less uniform diameter. At places, their end parts show 'simple' collapse structures. These tubes, partially similar in shape as those described by Buck \& Goldring (2003), are probably related to vertical burrows, which may have facilitated the upward migration of fluidised sand. The same authors, however, also hypothesise a non-organic genesis, such as dewatering pipes.

\subsection{Pillars and dish structures}

Short pillar-like tubes (Fig. 5B) (type A of Lowe, 1975) and dish structures (concave upwards curved laminae) are common in the upper part of thickand medium-bedded turbidites (class B and C of Pickering et al., 1986). However, they also occur in the middle part of some beds, but less frequently. The dish structures range in shape from flat to strongly curved. They are not always easily discernible. Sometimes their presence in apparently massive sandstone is marked only by small and isolated dike-like intrusions that are known as type-A pillars $(2-5 \mathrm{~cm}$ in diameter and few centimetres in length) (Lowe, 1975). The latter are also irregularly distributed in intervals with parallel lamination.

These pillars are uncommon, although in some cases 'echelon structures' formed by a series of inclined and irregular pillars (type D of Lowe, 1975) are visible. Diffuse vertical streaks or free surface pillars (type C of Lowe, 1975) appear sporadically at the top of some beds or in the vicinity of completely fluidised parts of beds; they may also be associated with convolute lamination.

\subsection{Sedimentary sills}

Sedimentary sills (actually more or less bed-parallel intrusions of fluidised sediment: Fig. 5C) occur in the upper laminated part of sandstone beds and are represented by irregular, elongated lens-like sand bodies, which are coarser-grained than the surrounding sediment and devoid of any primary sedimentary structures. The sills are usually parallel or subparallel to the bedding and they are often interconnected by vertical or subvertical tubes, thus creating a network of sills at different levels.
The thickness of individual sills is laterally variable, reaching a few centimetres; they often become thicker near the connection with vertical tubes. When a sill reaches the top of a bed, it may, at places, end in the form of a flat, elliptical structure composed of the same material as the sill (sandy pillow structures - sand volcano: Fig. 5D). Sporadically sills connected with vertical tubes display open funnel structures (Fig. 5E).

\subsection{Convolute lamination and associated structures}

Convolute lamination occurs in the top part of beds, as the $T_{c}$ division in a Bouma sequence. Locally climbing-ripple cross-laminae are present. The thickness of the convoluted interval may reach 50 $\mathrm{cm}$. Inside the convoluted interval antiform-shaped cusps occur, commonly with truncated tops, together with synform-shaped droplets and pseudonodules (Fig. 5E). In one case recumbent folds were observed.

At the transition between intact cross-laminae and convoluted lamination, pillars and dish structures are common. The frequency of these structures decreases upwards within the convoluted parts of the beds.

\section{Discussion}

Water-escape structures are fairly common in turbidite successions, especially in thick and massive coarse-grained sandstones (Dżułyński \& Walton, 1965; Allen, 1982; Lowe, 1982; Stow \& Johansson, 2000). However, abundant vertical tubular structures are seldom observed; this suggests that their formation and preservation require special conditions.

First of all, the observed sedimentary structures of the strata containing fluidised structures imply that the host sediment was deposited by a particular type of sediment gravity flows in a subaqueous environment, viz. high-density turbidity currents (sensu Lowe, 1982). In such flows, the coarse sandy material was subject to rapid mass deposition (due to intergranular friction in a concentrated dispersion near the sedimentary surface), which resulted in open grain packing and high amounts of interstitial fluid. The resulting open grain framework collapsed, during or after deposition, expelling fluid and resulting in the formation of fluid-escape structures (cf. Lowe, 1982).

The predominantly coarse character of the sands in the lower part of the freshly deposited turbidites 

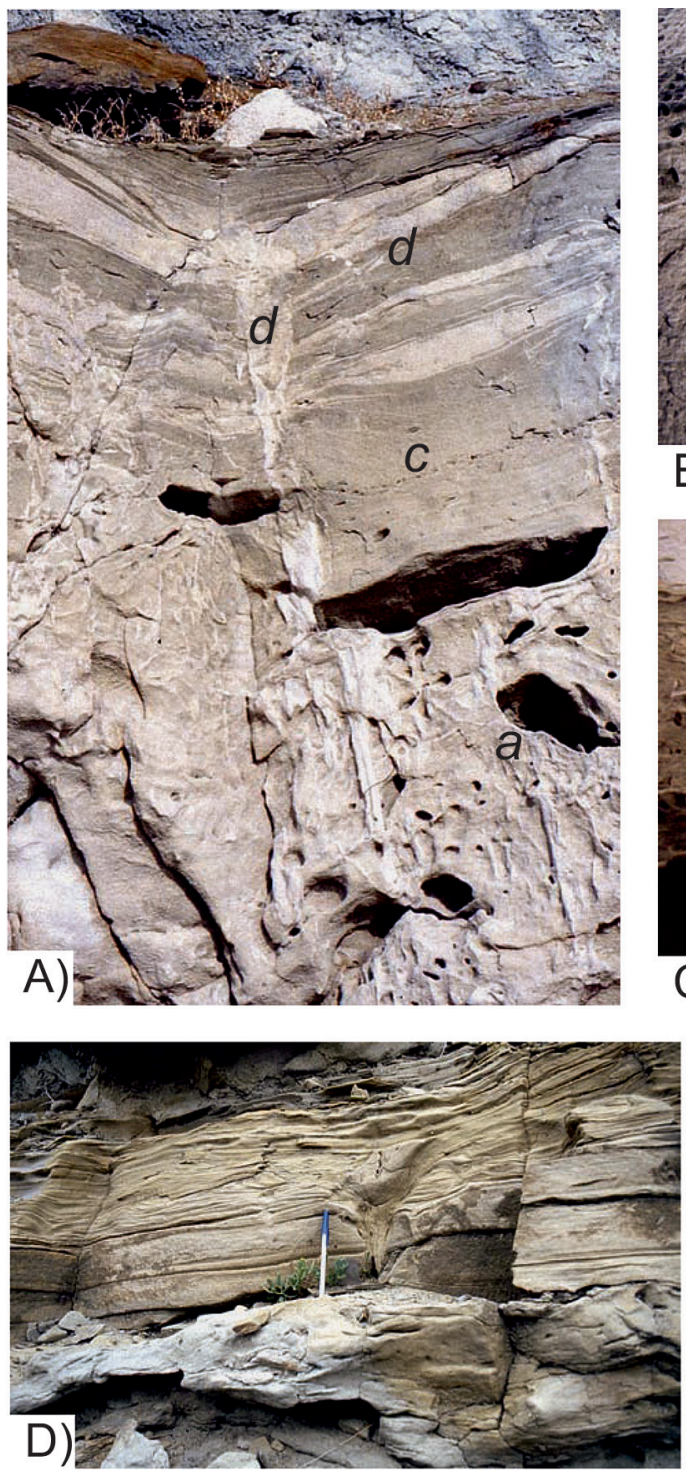
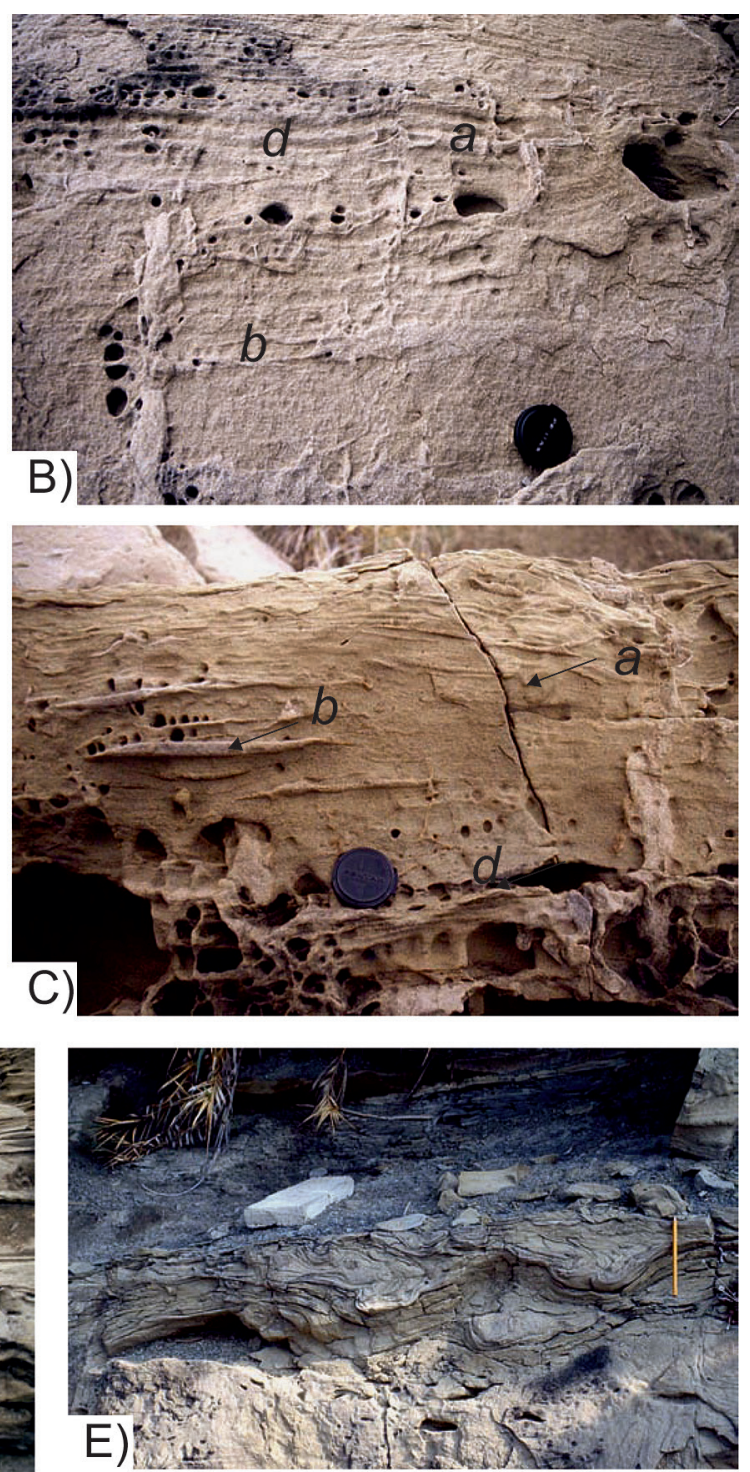

Fig. 5. Some soft-sediment deformation structures.

A: tubular structures. In the lower right part several tubes are visible that partly end at mudstone intraclasts (a); some tubes pass around the clasts (b); higher up the diameter of the main tube diminishes as it passes through a level of small clasts (c), and eventually this tube branches off into sills (d). The thickness of the visible part of the sandstone bed is $1.8 \mathrm{~m}$; B: short pillars and dishes (a); changes in the diameter of a tube (b); sandstone with crude parallel laminae (f); C: sills (a); lens-like bodies which are devoid of internal sedimentary structures (b), possibly representing a sill (note the presence of a layer of irregular cavities where mudstone intraclasts were plucked out; D: V-shaped, collapse structure probably within a tensional crack in the lower part of sandstone, where the primary lamination is relatively continuous. The layer below has been completely fluidised; E: convolute laminae developed at the highest part of slumped sandstone. Note the well-developed synform-shaped structures and hook-like recumbent folds.

resulted in a high permeability, which facilitated the upward pore-water movement. This created the fluid-escape structures described above, which are mostly vertical or sub-vertical. Several horizontal features occur, however, associated with these vertical structures in the upper part of the beds, together with other SSDS. This is related to the impediment of the upward flow, due to the lower permeability in these higher levels of the Bouma sequence, which consequently become less easily fluidised (Nichols et al., 1994). Moreover, mud and silt removed from the sea floor by the density currents could become incorporated as chunks which could contribute locally to interruptions of the pore-water movement, possibly also diverting its flow direction.

The sequence of events mentioned above can be reconstructed from the characteristics of the rocks and the SSDS in the succession under study. In fact, 
the fluid-escape structures and related SSDS are distributed mainly over the massive and apparently tightly packed portion of the beds. This characteristic of the lower coarse-grained part of the beds confirms that the liquefaction was from the consequence of a pressure exerted on the grains, which gave rise to an upward flow (cf. He et al., 2014, this issue). This process induced the formation of comparatively large fluid-escape tubes that propagated upwards with irregular spacing. Subsequently, the smaller tubes formed; they propagated also upwards and bifurcated within the upper parts of the fluidised beds, also generating sub-horizontal structures such as sills and sheets, parallel to the laminae. The genesis of these structures could be due to a reduced permeability that prompted a slower rate of fluid escape in the overlying finer-grained upper parts of the beds. Some of the major tubes, larger in diameter and transmitting a larger volume of pore water, were, nonetheless, able to penetrate through the top of the bed to form sand volcanoes (cf. the experimental model of Owen, 1996). Pervasive deformation obliterating all primary structures in some thick and medium beds possibly elicited prolonged fluidisation (Fig. 4) (cf. the chaotic unit of Owen, 1995).

In some cases the tubular structure stops abruptly upon reaching the finer-grained laminated part of a bed. The sediment dragged within the tube is then dispersed along the horizontal laminae or within ripples. Such structures can be explained by the occurrence of the escape process during deposition of the more turbulent and less dense part of the flow, which covered the thickest and most concentrated part of the flow, already deposited and subjected to over-pressure.

Both dish structures and short pillars may indicate incomplete sediment liquefaction, as the primary structures are commonly still well preserved or only slightly deformed. The flat or concave-up laminae pierced by isolated short pillars represent short-lived, limited fluidisation. The pronounced curvature of the dishes as well as the increase in the number of closely-spaced pillars reflect extensive fluidisation with a longer duration, as documented in experiments carried out by Lowe \& Lo Piccolo (1974), Tsuji \& Miyata (1987) and Nichols et al. (1994). Stow \& Johansson (2000) reported similar structures from ancient sandstone beds.

The convoluted laminae are due to two main processes: loading (Dżułyński, 2001) and dewatering (Lowe, 1975). It is not always possible to distinguish the precise origin of a convolute structure. It is possible that, in some cases, both processes acted simultaneously, with loading-induced deformation preceding and initiating dewatering, which subsequently took over as the main agent of fluidisation. The convolutions suggest hydroplastic deformation, not complete fluidisation. This effect is attributable to the presence of finer grains in the upper laminated part of the beds $\left(\mathrm{T}_{b}, \mathrm{~T}_{c}\right)$ that rendered the sediment more cohesive than the underlying coarser-grained sediments $\left(\mathrm{T}_{\mathrm{a}}\right)$. The indistinct internal laminae within the generally massive coarser parts of the turbidites may partially be related to the expulsion of trapped pore water (see Stowe \& Johanson, 2000).

Fluid escape is, indeed, the mechanism that formed most of the the SSDS, but it needs a trigger to start the injection of sand into overlying sediment. With respect to the observed deformation of the sediments as well as to the tectono-sedimentary setting of the Cilento Basin, the main triggers must have been the increase in pore-fluid pressure and a cyclic stress resulting from earthquake-induced seismic shocks (cf. Allen, 1986; Üner, 2014, this issue). The first agent could be the result of rapid deposition of sand (e.g. Lowe \& Lo Piccolo, 1974) and gravity-driven density currents (Dżułynski \& Walton, 1965; cf. Perucca et al., 2014, this issue) which leads to increased pore-fluid pressure within already deposited sediments. If this were the only agent involved here, however, this would imply that all top layers of the individual turbidites should show SSDS, but this is not always the case.

In contrast, the SSDS in the Punta Tresino section in fact are more consistent with characteristics that are commonly considered as diagnostic for an earthquake origin (Jones \& Omoto, 2000; Sarkar et al, 2014, this issue; Tian et al., 2014, this issue; Van Loon, 2014a, this issue), although it should be realised that these criteria should be applied with great care (Moretti \& Van Loon, 2014). The SSD (1) are laterally relatively persistent over the exposed cliff; (2) they are limited to specific stratigraphic horizons; (3) they are sandwiched between unaffected layers with a similar grain size; and (4) several deformed layers show a consistent deflection of the palaeocurrent trends from the usual direction.

The exposure of the section in a cliff allowed us to find out that the layers with SSDS can be followed laterally in a vertical interval of which the lateral continuity is clear all over the outcropping area. Moreover, this interval is confined between undeformed beds, suggesting that the deformation occurred during the depositional process or shortly afterwards, but before reaching a fair degree of consolidation. When an earthquake-induced shock occurred immediately after deposition, most of the water-saturated sand bed became quick sand and 
dewatering structures were created. The lack of dewatering structures in some beds might be ascribed to a too low magnitude of these shocks and/ or to a less easily fluidised bed. According to some authors (Atkinson, 1984; Audemard \& De Santis, 1991) earthquakes of magnitude less than 5 are not sufficient to cause liquefaction in sediments.

Seismic shocks played probably a significant role in the Cilento Basin, especially near its margin that was subjected to substantial tectonic remobilisation, as indicated by the presence in the succession of calcareous megaturbidites, olistostromes and slumps (see also Van Loon, 2014b, this issue). These deposits of unusual character were related to the structural re-organisation of the Cilento Basin and local tectonic movements, which lasted until the basin closure during the Late Miocene (Valente, 1993; Cavuoto et al., 2004).

\section{Conclusions}

The topmost unit of the Middle-Late Miocene S. Mauro Formation (Italy) shows evidence of soft-sediment deformation by a variety of mechanisms including fluidisation and liquefaction. It is probable that most SSDS were the effect of combined processes (cf. Van Loon \& Pisarska-Jamroży, 2014) that took place in a part of Cilento Basin situated close to the active margin of the overthrusting nappes and near its faulted margin.

As a consequence of this geological setting, frequent mass transport, mostly in the form of high-density turbidity currents, occurred frequently. The resulting rapid deposition of cohesionless coarse sand masses usually formed thick and very thick structureless beds that are well exposed along a coastal cliff. The rapid deposition of water-saturated turbidites led in the upper half of the beds to numerous fluid-escape structures. These structures originated during or shortly after deposition of the entire bed. The tectonic conditions certainly favoured the liquefaction of the freshly accumulated sediment. The good sorting of the sands further facilitated this process. The sands were probably from shelf sand that had been reworked.

Considering all the above, earthquakes seem to be the most plausible trigger mechanism for the development of the majority of the SSDS observed in this part of the turbidites. In addition to the relationship between the intensity of SSDS and magnitude of the shock and the distance from the epicentre, it is useful to understand the link between the energy and the intensity of earthquake-induced deformations in the sediments. In experimental studies, this relationship is quite clear and clearly proportional (e.g. Owen, 1996; Moretti et al., 1999) However, it must be kept in mind that some SSDS must be attributed to liquefaction and others to fluidisation. The former process develops with a lower intensity than the latter (seismite intensity scale of Hilbert-Wolf et al., 2009). Therefore, the convolutions, the dish and pillar structures, as well as some of the vertical tubular structures must have developed with less frequency than tubes associated with sills and fluidised beds. The analysis of this succession has shown that the first structures are much more abundant and affect mainly thicker turbidites, whereas the latter show local concentrations and affect less thick turbidites with a significant pelitic division $\left(\mathrm{T}_{\mathrm{e}}\right)$. These less thick turbidites tend in many cases to be amalgamated and to constitute chaotic layers ('slurries') or form completely fluidised beds.

The distribution of the SSDS allows to explain, because of the link with the intensity of the earthquakes, the associations of these structures in the beds. Such associations are partly different from the succession of the Oligo-Miocene Aljibe Flysch in southern Spain described by Stromberg \& Bluck (1998). The ideal sequence of events leading to the formation of water-escape structures described by these authors begins with a coarse-grained sandstone with or without convolutions, that passes into dark laminae and/or dish structures, followed by closely to widely spaced vertical tubes, inclined tubes, sills and pillars, and, finally, sand volcanoes. In the succession of the Cilento Basin discussed here, the lowermost part of a bed with SSDS is generally massive, which points at a rapid mass deposition and a consequent increase of the pore-fluid pressure. Above the massive interval, vertical tubes and scarce dish structures appear, succeeded by sills that are often connected with tubes, pillars and occasionally volcanoes or funnel-shaped structures at the end of the upwards migrating pore water. Microscopic analysis shows that the SSDS define the pathways for the circulation and escape of the pore waters. The vertical arrangement of the SSDS seems to depend on the rate of fluid escape within a bed.

\section{Acknowledgements}

Firstly we thank two anonymous referees for their many insightful suggestions which improved the manuscript. The authors are also grateful to Prof. Marek Wendorf for discussion and helpful assistance. Special thanks are due to the late Stan Dżułyński, who stimulated us to start this work, with whom we had fruitful discussions and who taught us to use all our energy to study sedimentary structures, both in field and in laboratory; now 
he is looking from Heaven. We also want to thank Prof. Tullio Pescatore, who has worked for years to strengthen the research between Polish and Italian researchers. Because of his premature death, he unfortunately cannot see this new product of research carried out jointly, but without him this would not have been achieved.

\section{References}

Allen, J.R.L., 1982. Sedimentary structures, their character and physical basis, Vol. 2. Developments in Sedimentology. Elsevier (Amsterdam) 30B, $663 \mathrm{pp}$.

Allen, J.R.L., 1986. Earthquake magnitude-frequency, epicentral distance, and soft-sediment deformation in sedimentary basins. Sedimentary Geology 46, 67-75.

Amore, F.O., Bonardi, G., Ciampo, G., De Capoa, P., Perrone, V. \& Sgrosso, I., 1988. Relazioni tra "Flysch interni" e domini appenninici: reinterpretazione delle formazioni di Pollica, San Mauro e Albidona nel quadro della evoluzione inframiocenica delle zone esterne appenniniche [Relations between the "internal Flysch" and Apennine domains: a reinterpretation of the Pollica, San Mauro and Albidona Formations in the intra-Miocenic evolution of the external zones of the Apennines]. Memorie della Società Geologica d'Italia 41, 285-297.

Atkinson, G., 1984. Simple computation of liquefaction probability for seismic hazard application. Earthquake Spectra 1, 107-123.

Audemard, F.A. \& De Santis, F., 1991. Survey of liquefaction structures induced by recent moderate earthquakes. Bulletin of the International Association of Engineering Geology 44, 5-16.

Beaudoin, B., Fries, G., Joseph, P. \& Paternoster, B., 1983. Sills greseux sédimentaires injectés dans l'Aptien supérieur de Rosaus (Drome). Comptes Rendus de l'Académie des Science de Paris 296, 387-392.

Buck, G.S. \& Goldring, R., 2003. Conical sedimentary structures, trace fossils or not? Observations, experiments, and review. Journal of Sediment Research 73, 338-353.

Cammarosano, A., Cavuoto, G., Danna, M., De Capoa, P., De Rienzo, F., Di Staso, A., Giardino, S., Martelli, L., Nardi, G., Sgrosso, A., Toccaceli, R.M. \& Valente, A., 2004. Nuovi dati sui flysch del Cilento (Appennino meridionale, Italia) [New data on the Cilento flysch (southern Apennines, Italy)]. Bollettino della Società Geologica d'Italia 123, 253-273.

Cavuoto, G., Martelli, L., Nardi, G., Valente, A., 2004. Depositional system and architecture of Oligo-Miocene turbidite successions in Cilento (Southern Apennines). GeoActa 3, 129-147.

Chen, J., Van Loon, A.J., Han, Z. \& Chough, S.K., 2009. Funnel-shaped, breccia-filled clastic dykes in the Late Cambrian Chaomidian Formation (Shandong Province, China). Sedimentary Geology 221, 1-6.

Cieszkowski, M., Malata, E., Oszczypko, N., Pescatore, T., Senatore, M.R., Ślączka, A. \& Valente, A., 1992. Rapporti tra le successioni di Monte Sacro e Monte della
Stella nel Flysch del Cilento (Appennino meridionale) [Relationship between the Monte Sacro and Monte Stella successions in the Cilento Flysch (southern Apennines)]. Rendiconti dell'Accademia di Scienze Fisiche Matematiche in Napoli s. IV, 69, 33-56.

Cieszkowski, M., Oszczypko, N., Pescatore, T., Ślączka, A., Senatore, M.R. \& Valente, A., 1994. Excursion A9: Deep-sea clastic sediments and associated megaturbidites and olistostromes (Cenozoic, Cilento, Southern Italy). [In:] G. Carannante \& R. Tonielli (Eds.): Pre-meeting fieldtrip guidebook 15th IAS Regional Meeting (April 1994, Ischia, Italy). International Association of Sedimentologists, 191-220.

Cieszkowski, M., Oszcsypko, N., Pescatore, T., Ślączka, A., Senatore, M.R. \& Valente, A., 1995. Megatorbiditi calcareo-marnose nelle successioni flyscioidi dell' Appennino meridionale (Cilento, Italia) e nei Carpazi orientali (Polonia) [Calcareous-marl megaturbidites in the flyschoid succession in the southern Apennines (Cilento, Italy) and in the western Carpathians (Poland)]. Bollettino della Società Geologica d'Italia 114, 67-88.

Cocco, E., 1971. Note Illustrative della Carta Geologica d'Italia alla scala 1:100.000, Foglio 209 Vallo della Lucania [Notes to the Geological Map of Italy 1:100,000, Sheet 209 Vallo della Lucania]. Servizio Geologico d'Italia (Roma), 45 pp.

Critelli, S., 1987. Petrologia delle areniti della Formazione di S. Mauro (Eocene sup.-Oligocene, Bacino del Cilento), Appennino meridionale [Petrology of the sandstones of the S. Mauro Formation (late Eocene-Oligocene, Cilento Basin), southern Apennines]. Memorie della Società Geologica d'Italia 38, 601-619.

Critelli, S., 1999. The interplay of lithospheric flexure and thrust accomodation in forming stratigraphic sequences in the southern Apennines foreland basin system, Italy. Rendiconti Lincei: Scienze Fisiche e Naturali 10, 257-326.

Critelli, S. \& Le Pera, E., 1990. Litostratigrafia e composizione della Formazione di Pollica (Gruppo del Cilento, Appennino meridionale) [Lithostratigraphy and composition of the Pollica Formation (Cilento Group, southern Apennines)]. Bollettino della Società Geologica d'Italia 109, 511-536.

Critelli, S. \& Le Pera, E., 1994. Detrital modes and provenance of Miocene sandstones and modern sands of the Southern Apennines thrust-top basins (Italy). Journal of Sedimentary Research A64, 824-835.

Dżułyński, S., 2001. Atlas of sedimentary structures from the Polish Flysch Carpathians. Institute of Geological Sciences, Jagiellonian University (Krakow), 132 pp.

Dżułyński, S. \& Walton, E.K., 1965. Sedimentary features of flysch and greywackes. Developments in Sedimentology. Elsevier (Amsterdam), 274 pp.

He, B., Qiao, X., Jiao, C., Xu, Z., Cai, Z., Guo, X., Zhang, Y. \& Zhang, M., 2014. Palaeo-earthquake events in the late Early Palaeozoic of the central Tarim Basin: evidence from deep drilling cores. Geologos 20, 105-123.

Hilbert-Wolf, H.L., Simpson, E.L., Simpson, W.S., Tindallw, S.E. \& Wizevichz, M.C., 2009. Insights into syndepositional fault movement in a foreland basin; 
trends in seismites of the Upper Cretaceous Wahweap Formation, Kaiparowits Basin, Utah, USA. Basin Research 21, 856-871.

Ietto, A., Pescatore, T. \& Cocco, E., 1965. Il flysch mesozoico del Cilento occidentale [The Mesozoic flysch of western Cilento]. Bollettino della Società dei Naturalisti in Napoli 74, 396-402.

Jones, A.P. \& Omoto, K., 2000. Towards establishing criteria for the identifying trigger mechanisms for softsediment deformation: case study of Late Pleistocene lacustrine sands and clays, Onikobe and Nakayamadaira Basins, northeastern Japan. Sedimentology 47, 1211-1226.

Lowe, D.R., 1975. Water escape structures in coarsegrained sediments. Sedimentology 22, 157-204.

Lowe, D.R., 1976. Subaqueous liquefied and fluidized sediment flows and their deposits. Sedimentology 23, 285-308.

Lowe, D.R., 1982. Sediment gravity flows. II Depositional modes with special references to the deposits of high density turbidity currents. Journal of Sedimentary Petrology 52, 279-297.

Lowe, D.R. \& Lo Piccolo, R.D., 1974. The characteristics and origin of dish and pillar structures. Journal of Sedimentary Petrology 44, 484-501.

Martelli, L., Nardi, G., Bravi, S., Cavuoto, G. \& Toccaceli, R.M., 2005. Note illustrative della Nuova Carta geologica d'Italia alla scala 1:50.000: Foglio 503 "Vallo della Lucania" [Notes to the new Geological Map of Italy, 1:50,000, Sheet 503 'Vallo della Lucania']. Presidenza del Consiglio Dei Ministri - Dipartimento per i Servizi Tecnici Nazionali - Servizio Geologico D'Italia. S.EL. CA. (Firenze), $86 \mathrm{pp}$.

Meulenkamp, J.E. \& Sissingh, W., 2003. Tertiary palaeogeography and tectonostratigraphic evolution of the northern and southern Peri-Tethys platforms and the intermediate domains of the African-Eurasian convergent plate boundary zone. Palaeogeography, Palaeoclimatology, Palaeoecology, 196, 209-228.

Moretti, M., Alfaro, P., Caselles, O. \& Canas, J.A., 1999. Modelling seismites with a digital shaking tables. Tectonophysics 304, 369-383.

Mutti, E., Davoli, G., Mora, S. \& Papani, L., 1994. Internal stacking patterns of ancient turbidite systems from collisional basin. [In:] P. Weimer, A. Bouma \& B.F. Perkins (Eds): Submarine fans and turbidite system. GCSSEPM Foundation 15th Annual Research Conference (December 1994, Houston, Texas), 257-268.

Mount, J.F., 1993. Formation of fluidization pipes during liquefaction: examples from the Uratanna Formation (Lower Cambrian), South Australia. Sedimentology 40, 1027-1037.

Nichols, R.J., Sparks, R.S.J. \& Wilson, C.J.N., 1994. Experimental studies of the fluidization of layered sediments and the formation of fluid escape structures. Sedimentology 41, 233-253.

Owen, G., 1995. Soft-sediment deformation in Upper Proterozoic Torridonian sandstones (Applecross Formation) at Torridon, Northwest Scotland. Journal of Sedimentary Research A65, 495-504.
Owen, G., 1996. Experimental soft-sediment deformation: structures formed by the liquefaction of unconsolidated sands and some ancient examples. Sedimentology 43, 279-293.

Parise, O. \& Beaudoin, B., 1986. Les filons grèseux du Numidien dans leur cadre paléomorphologique (Sicile et Tunisie). Comptes Rendus de l'Académie des Sciences de Paris 304, 129-134.

Perucca, L.P., Godoy, E. \& Pantano, A., 2014. Late Pleistocene-Holocene earthquake-induced slumps and soft-sediment deformation structures in the Acequion River valley, Central Precordillera, Argentina. Geologos 20, 147-156.

Pescatore, T., 1966. Strutture sedimentarie nel Flysch del Cilento occidentale [Sedimentary structures in the western Cilento flysch]. Geologica Romana 5, 99-116.

Pickering, K.T., Hiscott, R.N. \& Hein, F.J., 1989. Deep marine environments. Unwin Hyman (London), 416 pp.

Russo, M., Zuppetta, A. \& Guida, A., 1995. Alcune precisazioni stratigrafiche sul Flysch del Cilento (Appennino meridionale) [Some stratigraphic clarifications on the Cilento Flysch (southern Apennines)]. Bollettino della Società Geologica Italiana 114, 353-359.

Sarkar, S., Choudhuri, A., Banerjee, S., Van Loon, A.J. \& Bose, P.K., 2014. Seismic and non-seismic soft-sediment deformation structures in the Proterozoic Bhander Limestone, central India. Geologos 20, 89-103.

Ślączka, A. \& Thompson, S., 1981. A revision of the fluxoturbidites concept based on type examples in the Polish Carpatian Flysch. Annales de la Société géologique de Pologne 51, 3-44.

Stow, D.A.V. \& Johansson, M., 2000. Deep-water massive sands: nature, origin and hydrocarbon implications. Marine and Petroleum Geology 17, 145-174.

Stromberg, S.G. \& Bluck, B., 1998. Turbidite facies, fluid-escape structures and mechanism of emplacement of the Oligo-Miocene Aljbe Flysch, Gibraltar Arc, Betics, southern Spain. Sedimentary Geology 115, 267-288.

Tsuji, T. \& Miyata, Y., 1987. Fluidization and liquefaction of sand beds - Experimental study and examples from Nich inan Group. Journal of the Geological Society of Japan 11, 791-808.

Moretti, M. \& Van Loon, A.J., 2014. Restrictions to the application of 'diagnostic' criteria for recognizing ancient seismites. Journal of Palaeogeography 3, 13-24.

Tian, H.S., Zhang, B.H., Zhang, S.H. \& Lü, M.Y., 2014. Neogene seismites and seismic volcanic rocks in the Linqu area, Shandong Province, E China. Geologos 20, 125-137.

Üner, S., 2014. Seismogenic structures in Quaternary lacustrine deposits of Lake Van (eastern Turkey). Geologos 20, 79-87.

Valente, A., 1993. Studi geologici e sedimentologici sulla successione miocenica di Monte Sacro (Flysch del Cilento, Appennino meridionale) [Geological and sedimentological studies on the Miocene succession of Monte Sacro (Cilento Flysch, southern Apennines)] Unpublished Ph.D. Thesis, Federico II University (Naples), 170 pp.

Van Loon, A.J., 2014a. The life cycle of seismite research. Geologos 20, 61-66. 
Van Loon, A.J., 2014b. The Mesoproterozoic 'seismite' at Laiyuan (Hebei Province, E China) re-interpreted. Geologos 20, 139-146.

Manuscript submitted 28 December 2013

Van Loon, A.J. \& Pisarska-Jamroży M., 2014. Sedimentological evidence of Pleistocene earthquakes in NW Poland induced by glacio-isostatic rebound. Sedimentary Geology 300, 1-10. 